\title{
Speak blanc
}

\author{
Sylvain Campeau \\ Hugh Hazelton (translator)*
}

Submetido em 11 e aprovado em 25 de abril de 2021.

Résumé : Hugh Hazelton traduit le poème Speak blanc, de Sylvain Campeau, poète et critique d'art québécois. Le poème a été publié en 2019 en version intégrale, après avoir été adapté pour l'audiovisuel par Alain Lefort au Festival International du Film sur l'Art (FIFA) 2021 à Montréal. Il s'agit d'un long poème qui examine l'enracinement du peuple québécois; leur lutte pour se préserver comme un peuple, surtout à travers de leur langue, sous le régime britannique; l'impact de l'arrivée d'immigrants de partout dans le monde qui entrent à la sphère francophone, tout en gardant le souvenir de leurs propres langues et cultures; ainsi que des réflexions sur le destin du Québec français dans le futur. L'auteur parle aussi des peuples autochtones et de leurs langues et liens entre eux, ainsi que d'un nouveau argot multilingue qui surgit dernièrement parmi les jeunes de toutes les origines. Ce texte est une version réduite de l'original.

Mots-clés: Speak blanc. Sylvain Campeau. Hugh Hazelton. Traduction. Poésie québécoise.

\begin{abstract}
Hugh Hazelton is the translator of the poem "Speak blanc", by Sylvain Campeau, a poet and art critic in Québec. The poem was published in full in 2019, and was then adapted for a video by Alain Lefort for the 2021 Festival International du Film sur l'Art (FIFA) in Montréal. It is a long poem that examines the roots of the Quebec people; their struggle to preserve themselves as a people, especially through their language, under British rule; the impact of the arrival of immigrants from all over the world who enter the Francophone sphere, while retaining the memory of their own languages and cultures; as well as reflections on the fate of French Quebec in the future. The author also talks about indigenous peoples and their languages and links between them, as well as a new multilingual slang that is emerging among young people of all origins lately. This text is a shortened version of the original.
\end{abstract}

Keywords: Speak blanc. Sylvain Campeau. Hugh Hazelton. Translation. Quebec poetry. 


\section{Introduction}

Sylvain Campeau est poète, critique d'art, essayiste et commissaire d'exposition. Il a publié 7 recueils de poésie, des essais sur les arts visuels et une anthologie de poètes québécois. Il a aussi réalisé, avec la collaboration de l'artiste sonore Chantal Dumas, un CD intitulé Havres, offert avec son dernier recueil de poésie, Dire encore après. C'est dans ce dernier que le poème "Speak Blanc » a été publié. Il existe aussi en version vidéo, une réalisation d'Alain Lefort présentée au Festival International des films sur l'art (FIFA). Un autre vidéopoème a été crée avec l'aide de Mériol Lehmann, Orée du désastre. Sylvain Campeau est membre de la Maison de la poésie de Montréal.

Le poème «Speak blanc » existe en version complète dans le recueil Dire encore après, publié en 2019 aux éditions Triptyque. Le présent texte est une version raccourcie, modifiée pour les besoins de son adaptation vidéo, réalisée par Alain Lefort et présentée au Festival international du film sur l'art (FIFA) de 2021 à Montréal.

Hugh Hazelton est un écrivain et traducteur qui se spécialise dans la comparaison des littératures du Canada anglais et du Québec avec celles de

\section{Introduction}

Sylvain Campeau is a poet, art critic, essayist and curator of art exhibitions. He has published seven books of poetry, a number of essays on the visual arts, and an anthology of Québec poets. $\mathrm{He}$ has also created, in collaboration with the sound artist Chantal Dumas, a CD titled Havres, which comes with his latest book of poems, Dire encore après, that contains the poem "Speak Blanc". In addition, there is a video of the poem, directed by Alain Lefort and presented at the Festival International des films sur l'art (FIFA). Another of his poems, Orée du désastre, has been made into a video poem with the help of Mériol Lehmann. Sylvain Campeau is a member of the Maison de la poésie de Montréal.

The poem "Speak Blanc" was published in full in the collection Dire encore après, published by Les éditions Triptyque in 2019. The present text is a shortened version that was modified and adapted for a video of the same title directed by Alain Lefort and screened at the Festival international du film sur l'art (FIFA) in Montreal in 2021.

Hugh Hazelton is a writer and translator who specializes in the 
l'Amérique latine, ainsi que dans la littérature hispano-canadienne. Il a écrit quatre livres de poèmes et traduit de du français, de l'espagnol et du portugais vers l'anglais; sa traduction de Vétiver (Signature, 2005), un livre de poèmes de Joël Des Rosiers, a gagné le prix du Gouverneur Général pour la traduction français-anglais en 2006. Il est professeur honoraire d'Espagnol à l'Université Concordia à Montréal, ancien codirecteur du Centre international de traduction littéraire de Banff en Alberta, et membre de la Maison de la poésie de Montréal.

Vidéos :

« Speak Blanc» (extrait):

https://vimeo.com/516503249

Orée du désastre (avec sous-titres anglais et espagnols) :

https://mlehmann.ca/oree-du-desastre

Nous ne sommes pas arrivés

à ce qui commence

Nous continuons à survivre à ce qui ne semble pas pouvoir être comparison of Canadian and Quebec literatures with those of Latin America, as well as in the work of Latin American writers of Canada. He has written four books of poetry and translates from French, Spanish, and Portuguese into English; his translation of Vétiver (Signature, 2005), a book of poems by Joël Des Rosiers, won the Governor General's award for French-English translation in 2006. He is a professor emeritus of Spanish at Concordia University in Montreal and former codirector of the Banff International Literary Translation Centre in Alberta.

Videos:

"Speak Blanc" (extract): https://vimeo.com/516503249

Disaster's Edge (with English and Spanish subtitles):

https://mlehmann.ca/oree-du-desastre 


\section{Speak blanc}

Il fait si mal d'entendre ces mots gourds battus par un rythme qui n'est plus le nôtre Vocables malades pour parler bredouille comme un mollusque bivalve, binaire, bizarre

Et c'est comme...

Et c'est like...

Et c'est genre...

Ou bien nice

Mais, que ce soit swag ou dead rien ne vient comme devrait l'image n'y est comme pas, genre

Speak blanc pour faire bref

En se faisant bouche autre nous acquiesçons à l'ennemi en nous qui cherche l'inédit dans le pillage et le plagiat de la langue envahissante, cet espéranto actualisé du commerce et quand ce n'est pas la langue c'est son esprit tout de même et tout du même qui complète et achève de médire dans un phrasé qui copie et ânonne des ions atones d'homélies étrangères

Ket, mon patnay

Sois pas sezi trop

Ni freken, quoi

Vag sur la langue

qu'on ne prenne pas une laide

Pour sou sa gloser correct ${ }^{1}$

Dieu qu'il est loin le temps de nos parlures de chaque côté des cléons des clôtures

Désormais il faut speaker blanc en potée de mots et célébrer la langue du vécu collée à l'immédiat celle du tapage aigu des egos Parlons bègue blanc d'Amérique

\section{Speak Blanc}

It's so painful to hear those stiff words beaten by a rhythm that is no longer ours Sick terms to speak empty-handed like a bivalve, binary, bizarre mollusk And it's like...

Et c'est like...

Et it's comme...

Ou bien nice

But, whether it be swag or dead nothing comes as it should the image isn't like there, comme Speak blanc to be brief

In making another mouth we acquiesce to the enemy in ourselves that searches the unheard of in the pillaging and plagiarism of the invading language, that updated esperanto of business and when it's not the language it's the spirit all the same and all of the same that completes and ends up maligning in a phrasing that copies and recites droning on the atonal ions of foreign homilies

\section{Ket, mon patnay \\ Soia paa sezi trop \\ Ni freken, quoi \\ Vag sur la langue \\ qu'on ne prenne pas une laide \\ Pour sou sa gloser correct}

God it's been a long time since our palaver on each side of half doors and fences

From now on we'll have to speaker blanc in a pork stew of words and celebrate the language we've lived glued to the immediate that of the sharp racket of egos Let's speak stammered white of America 
pour pouvoir dire

qui je suis

qui je suis qui je suis

dans toutes les téléréalités

pavoisant, diaphane, dans la ferveur

de qui veut ses 15 minutes de gloire tabloïd

repris à la une de la convergence identitaire et médiatiquex

Speak blanc ou blanco

Avec, exhibé, l'emblême

tlaātlācuezonanihcuilōllì ${ }^{2}$

Nos mots sont comme nos forêts

fardoche 100 fois reprise

depuis les coupes à blanc

petite broussaille qui fait tonsure

et mime d'arbres et de splendeurs échevelées

nos phrases se cabrent comme nos rivières

harnachées et endiguées

Il est vrai que, chez nous, lacs et forêts, plans d'eau et fournées végétales abondent

on sait le sous-sol inondé de richesses telles

qu'on en balafrerait la terre pour l'ouvrir comme une amante qu'on croit aimer dans le viol

Nous aurons bientôt, en elle, trop fait mines de rien

sans retenue et sans pactole

pour alimenter cartels et triades

des énergies et métaux

créant les nouvelles idoles

de la bourse et des marchés mondiaux

Nous adorons trop ces fossiles

qui ressurgissent par forage et pénétration

chimique

carbone d'un autre âge

pour consommation dinosaure

nous qui savons ce qu'il en coûte pourtant de veiller à ne pas disparaître in order to say

who I am

who I am who I am

in all the telerealities

showing off, diaphanous, in the fervour

of someone who wants his 15 minutes of tabloid glory

picked up on the first page of the identity and media convergence

Speak blanc or blanco

with, exhibited, the emblem

tlaātlācuezonanihcuilōlli ${ }^{2}$

Our words are like our forests

undergrowth rerun 100 times

since the clear-cuts

low brush that makes a tonsure

and mime of trees and dishevelled splendours

our phrases rear up like our rivers

harnessed and dammed up

It's true that, among us, lakes and forests, expanses of water and batches of green abound

we know the basement inundated with such riches

that we'd slash the land

to open it up like a lover

that we think we love as we rape her

We'll soon have, in her, looked away too many times

without restraint and without a stash

to feed cartels and triads

of energies and metals

creating new idols

of the stock market and world markets

We adore those fossils too much

as they resurge through drilling and chemical penetration

carbon of another age

for dinosaur consumption

yet we who know what it costs

to keep watch so as not to disappear 
présents toujours

malgré le nécessaire aliment qui s'épuise

Nous à qui on avait enseigné

le labeur et le sou durement gagné

dans un misérabilisme catho de rigueur,

nous nageons maintenant dans une plénitude

qui nous endort et nous fait dépensiers

Ce que je suis est

ce que je fuis

(Civis Romanus Sum

Ich bin ein Berliner)

Je suis d'Oka

Ekuanitshit nutshipan ${ }^{3}$

Warrior ou Indien blanc

à ne plus savoir

où donner de l'identité!

venu au monde nouveau

accueilli âprement par cette terre de Caïn

Ugs'tqamui ${ }^{4}$

Je suis du nord comme du sud

fondateur de Saint-Louis, de Chicago, de Détroit

je suis de toundra et de plaines, de montagnes et de neige

Qallunaujagulualutsalaurit ${ }^{5}$

of_a

Je fus esclave

et je fus maître

j'ai oublié l'un et amnistié l'autre

à grands traits et manifestes

de refus globaux et de replis stratégiques

Je fus surtout

Brûlé à tous les soleils de la Huronie

marchand à Michilimackinac

Je suis aujourd'hui

pour moi-même

l'un et l'autre

tour à tour

à nouveau ever present

despite the necessary supplies that are running out

We who had been taught

labour and money hard earned

in a Catholic miserabilism de rigueur,

we swim now in an abundance

that lulls us to sleep and makes us spendthrift

What I am is

what I flee

(Civis Romanus Sum

Ich bin ein Berliner)

I am from Oka

Ekuanitshit nutshipan ${ }^{3}$

Warrior or White Indian

not knowing any more

where to give identity!

arriving in a new world

bitterly welcomed by this land of Cain

Ugs'tqamui ${ }^{4}$

I'm from both north and south

founder of Saint Louis, Chicago, Detroit

I'm of tundra and plains, mountains and snow

Qallunaujagulualutsalaurit ${ }^{5}$

of_a

I was a slave

and I was a master

I forgot the one and amnistied the other with great deeds and manifestos

global refusals and strategic retreats

I was above all

burned by all the suns of Huronia

a merchant in Michilimackinac

I am today

for myself

one and the other

alternately

again 
un tyran qui s'ignore

Wendat yewennóntahkwih ${ }^{6}$

Nous sommes, voyez-vous, au-delà de toute critique

Car nous venons de si loin en noirceur

que la lumière d'aujourd'hui fait foi de tout Finis, les fils déchus des vieilles montagnes râpées du nord

Nous sommes triomphes

d'avoir été longtemps perdants anciens porteurs d'eau la dilapidant depuis

Nous croyons en nous-mêmes

discourant, compétents et performants, la langue à terre

dans le jargon sourd et dur

le phonème ébouriffé à la Godin

qui a tant parlé pauvre pour honorer le pauvre

et déviarger le profiteur,

parlé en ce patois qui n'est plus

pendant que d'autres pavoisent

et plastronnent en chiac

Nous avons la fierté d'être si grande qu'elle peut se passer de toute fondation

Nous sommes

et cela suffit

Nous sommes

encore

à parler seulement

en blanc phonème

Nous ne sommes pas seuls pourtant car tous parlent en nous et nous étourdissent

Nous avons la foi de tout et de tous dans la Babel séduisante de notre terre froide et pourtant amène Bouche ouverte du Saint-Laurent sur les découvertes et les arrivées eau étonnée d'être encore et de ne pas manquer d'oxygène a tyrant without knowing it

Wendat yewennóntahkwih ${ }^{6}$

We are, you see, beyond all criticism

Because we come from so deep in darkness that the light today reveals it all

Finished, the fallen sons of scraped mountains of the north

We are triumphs of long being losers

bygone drawers of water squandering it afterwards

We believe in ourselves holding forth, competent and effective, tongues hanging down to the ground in the deaf, hard jargon the tousled phoneme à la Godin which has so long spoken poor to honour the poor and screw the profiteer, spoken in this patois that is no longer while others show off and boast in Chiac

We enjoy the pride of being so great that it can do without any foundation

We are and that's enough

We are

still

speaking only

in white phonemes

But we aren't alone

because everyone speaks in us and dazes us

We prevail over everything and everyone in this seductive Babel of our cold yet pleasing land Open mouth of the St. Lawrence on the discoveries and the arrivals water surprised at still existing and not being short of oxygen 


\section{Speak blanc}

Et pourtant

Nous sommes simples, directs, sans fioritures

de droiture franche et efficace

ainsi que nous nous voulons

ni langue de bois ni langue de roi

ne sont pour nous

Oui, nous avons l'ennemi en nous

et il a pour nom paresse et complaisance

Nous avons trop émulé les maîtres chez nous

Ceux-là qui ont tant espéré

et espèrent encore

que l'oubli de ce que nous sommes

nous amène à ne plus être tels

que nous pourrions nous vouloir, émancipés de tout ce que l'on croit posséder et qui nous possède

depuis la révolution languide

qui nous a donné l'orgueil d'avoir rattrapé

les avoirs nécessaires à notre rédemption sur terre
Allons-nous achever
à nous seuls
le rêve de Durham
si forts de nous
que nous ouvrons la maison à tous vents
et qu'y entre qui veut
et souhaite n'être pas seul parmi nous

Car nous sommes l'avent et l'après de tout peuple

Nous sommes neufs et frais

sur une terre ancienne

d'installation récente

et de colonisation ardue

Nous connaissons le fait d'arriver et d'occuper un lieu réfractaire

Les autres adviennent ainsi

comme nous sommes venus nous-mêmes

migrants de tous les vents et souffles et langues
Speak blanc

And yet

We are simple, direct, without frills

uprightly frank and efficient

the way we want ourselves to be

no political or royal cant

for us

Yes, we have the enemy in ourselves whose name is laziness and indulgence We've over emulated the masters of our own house

Those who have waited so long

and wait still

for the forgetting of what we are

to make us no longer be those

that we might want to be,

emancipated from all that we think we possess

and that possesses us

since the languid revolution

that gave us the satisfaction of having recaptured

the necessary assets for our earthly redemption

Will we ever finish

on our own

Durham's dream

so strong-minded

that we open the house to the four winds

and all who want can enter

For we are the advent and afterward of all peoples

We're new and fresh

in an ancient land

newly installed

and arduously colonized

We know what it is to arrive and occupy a resistant place

The others come

just as we came ourselves

migrants of all the winds and breaths and languages 
Et nous savons qu'ils sont nombreux et friands

ceux-là qui viennent en terre d'ici

devenir nos compagnons et compagnes

Ils veulent de nous

savoir ce dont nous sommes

et nous n'avons rien à leur dire

sinon de nous parler

comme nous leur parlons

Oui, ils nous parlent français

mais de la langue seule

et non du cœur,

eux dont les enfants parlent l'une,

parlent l'autre, sans aller

jusqu'à l'âme d'aucune

Comment pourrait-on le leur reprocher

car, de nous, ils n'ont eu que la langue

à tirer

Je reckon

qu'un day

à force de revenir back

y'aurait pu rien à aller on

Mourir poliment

ça, nous saurons

Entendons-nous

Nous tolérons trop

en nous déjà

l'ignorance de ce que nous avons été

au profit d'un Eldorado

des ressources gaspillées et de capital ronflant

dans nos rencontres inopinées

au Costco, Walmart, Loblaws et Rona

de nos quartiers et banlieues en bonnes rangées

Comment pourrions-nous enseigner

à ceux qui nous surviennent

ce que nous avons été

quand on n'en a plus souvenir

ni mémoire
And we know they're numerous and eager

those who come to our land

to become our companions

They want to know

what we are made of

and we have nothing to tell them

except to speak to us

as we speak to them

Yes, they speak to us in French

but only from the tongue

and not the heart,

those whose children speak one,

speak the other, without going

to the soul of either

How can we reproach them

when all we've given them is a tongue to stick out

Je reckon

qu'un day

à force de revenir back

y'aurait pu rien à aller on

To die politely

that, we'll know how to do

Let's listen to ourselves

We already tolerate

too much in ourselves

the ignorance of what we've been

for the benefit of an Eldorado

of wasted resources and pompous

capital

in our unexpected encounters

at Costco, Walmart, Loblaws and Rona

in our neighbourhoods and suburbs in neat

rows

How could we teach

those who come after us

what we have been

when we no longer have any recollection or memory 


\author{
Bientôt, \\ nous aurons, \\ du vierge, \\ tout incendié \\ et de nous \\ tout décompagnonné \\ et notre terre obligeante \\ bovidé empanaché et buté \\ reposera sans nous \\ dans les mille méandres des eaux \\ d'où émergeront encore \\ quelques barrages déconnectés \\ en plan laissé ce nord pays
}

Soon,

we will have

burned up all

that's virgin

and broken all companionship

and our obliging land

bovid, antlered and stubborn

will rest without us

in the thousand meanders of the waters

from which a few disconnected dams

will still emerge

left stranded this north country

\section{Ditwnanaan $^{7}$}

\section{Notes}

* Professeur émérite d'espagnol, Université Concordia, Montréal, Québec, Canada. hhazelton@videotron.ca.

1 Cette section est une adaptation libre à partir de mots issus des langues créole haïtien et arabe, devenus des expressions singulières d'un joual montréalais quand mélangés au français.

ket : wow

patnay : ami

czi (sezi) : choqué

freken : irrespectueux/énervé

vag (sur) : laisse tomber

prendre une laide : se faire humilier

sou sa : avoir envie de

2 Peint d'un motif de lys blanc.

Le terme décrit aussi le bouclier de Huixtohcihuātl, déesse aztèque de la fertilité

Du nahuatl, langue parlée par les Aztèques, appartenant à la famille des langues uto-aztèques. C'était la langue parlée à Tenochtitlan (Mexico). Elle est aujourd'hui considérée comme morte. Les dialectes qui en sont issus, sont encore parlés par plus d'un million de personnes au Mexique.

3 Je viens de Ekuanitshu (Mingan).

4 Je suis venu au monde. D'une langue presque oubliée, réapprise, le mi'kmaq. ugs'tqamui (uk:sêt.hka·mu·i)

5 Speak White en Inuktitut, version écriture syllabique. Les Blancs en inuktitut, ce sont les anglophones, le mot est qallunat. Les francophones ont un autre

\section{Notes}

* Emeritus Professor of Spanish, Concordia University, Montreal, Quebec, Canada. hhazelton@videotron.ca.

1 This section is a free composition created with words from Haitian Creole and Arabic, which have become distinctive expressions of a new Montreal joual (slang) when mixed with French.

ket : wow

patnay : friend

czi (sezi) : shocked

freken : disrespectful, annoyed

vag (sur) : never mind

prendre une laide : to be humiliated

sou sa : to feel like

2 "Painted from a motif of white lily."

The term also describes the shield of Huixtohcihuātl, the Aztec goddess of fertility. From Nahuatl, the language spoken by the Aztecs, belonging to the Uto-Aztec family of languages. It was the language spoken in Tenochtitlan (Mexico City). It is now considered dead. The dialects that issued from it are still spoken by more than a million people in Mexico.

3 "I come from Ekuanitshu" (Mingan).

4 "I came into the world," from Mi'kmaq, a language almost forgotten and then learned once more. Ugs'tqamui (Udk:sêt $\cdot h k a \cdot m u \cdot i)$.

5 "Speak White" in Inuktitut, in syllabic writing. White people in Inuktitut are Anglophones: the word is "qallunat." Francophones have another name. The term does not have the connotation of 
nom. L'expression n'a pas la connotation de Speak White; elle est neutre, factuelle.

6 Je parle wendat.

7 Amen en métchif (orthographe anglaise michif), déformation du vieux mot français métif, ou mitchif, langue mixte à base du cri et du français parlée par certains membres de la nation métisse au Canada et dans le Nord des États-Unis.
"Speak White": it is neutral, factual.

"I speak Wendat."

7 "Amen" in Métchif (spelled Mechif in English), a deformation of the Old French word "Métif", or "Mitchif," a mixed language based on Cree and French spoken by certain members of the Métis nation in Canada and the northern United States. 